\title{
Examining the Empathetic Tendency Levels of theAthletes Dealing with Team and Individual Sports
}

\author{
Selçuk BUĞDAYCI ${ }^{1}$, Uğur ABAKAY², Zeliha ABAKAY²
}

\author{
${ }^{1}$ Selcuk University, Faculty of Sport Science, Konya, Turkey. \\ ${ }^{2}$ Gaziantep University, School of Physical Education and Sports, Gaziantep. \\ Address Correspondence to S, Buğdaycı, e-mail: sbugdayci@gmail.com
}

\begin{abstract}
The aim of this study is to determine the empathetic tendency levels of the athletes dealing with team and individual sports, and to specify whether there is a statistically significant difference concerning gender and sports experience variables. In total, 524volunteer athletes (232 males and 292 females) participated in the study, whose ages ranged between 15 and 27 . The "Empathy in the Sports Environment (ESE)" scale, which was developed by Erkuş and Yakupoğlu (2001), was used in the study for the data collection. The SPSS 22.0 package program was used in the analyses of the data. The Independent Samples T test was employed for the paired comparisons, and the Spearman's rho correlation analysis for determining the relations among the variables. The significance level was accepted as $\mathrm{p}<0.05$ in the evaluation of the results. As the conclusion of the study, it was determined that there was statistically no significant difference between the athletes dealing with team and individual sports concerning the emotional empathy dimension; however, it was determined that the athletes dealing with team sports gained higher scores in the prediction dimension; it was found that the emotional empathy scores of the female athletes were higher for the gender variable and male athletes had higher scores concerning the prediction dimension. Considering the sports experience dimension, it was determined that the higher the years of experience, the higher the levels of emotional empathy and prediction.
\end{abstract}

Key Words: Empathy, team athlete, individual athlete

\section{INTRODUCTION}

In the sports environment, particularly during the sports competitions, it is conceivable that the empathetic skills of the athletes are efficient in the sports branch. Particularly in the team sports, the athlete's use of empathetic skills towards the team mates, trainer, and the opponents can be an important factor in predicting his/her possible behaviors, in forming the team spirit, and thus, in the team success. It is not wrong that the sense of team unity of the athletes, who have high level of empathetic skills,is high as well. Considering the fact that the teams with a high sense of team unity will be more successful, it is suggested that the empathy levels of the athletes constituting the team should be improved (9).

There are different definitions of empathy today. These are mostly defined as looking from the perspective of the interlocutor by putting oneself into the shoes of him/her, and the process of understanding his/her thoughts accurately, feeling it and conveying it to him/her; it is generally discussed under two titles as the cognitive and emotional empathy $(8,14,15,23,12,11)$.

It is stated that empathy is one of the basic human characteristics that contributes to harmony. Therefore it is inevitable that empathy is used in all aspects of life (5). Empathy is both a cognitive and an emotional process and it is employed by imagining oneself in the position of another and remembering his/her similar experiences. Empathy also produces reactions appropriate to these sharings of emotions and thoughts (like helping the ones in need) (6).

Empathy is a verbal response reflecting the motive behind the emotions and emotional content 
of the speech. Not being used much in the daily life, empathy is one of the most difficult components of communication skills that should be learned and comprehended (26). Empathy can also be defined as being objectively aware of emotions and opinions of others as well as their various meanings, and representatively experiencing the emotions and opinions of them (6).

The studies conducted to measure the empathy skills and tendencies of individuals are generally based on a certain listing of empathetic reactions (1). In other words, individuals might be in harmony with the society since they can show empathy, or similarly, they might have developed their sense of empathy since they can comply with the society. However, whatever the direction of the relationship, the fact that there is a relationship between the empathy and certain variables emphasizes the importance of empathy in our daily life (10).

As is understood from the studies conducted on this field in the literature, empathy makes important contributions to the level of the relationships among individuals. In this context, it can be stated that the higher the emphatic approach implemented in the sports environment the higher it will contribute to success. In this study, which was conducted in the light of these pieces of information, initially, answers were sought for the questions, is there a difference between the empathic tendencies of athletes dealing with team or individual sports?, and do the gender and sports experience have any influence on the empathetic tendency?

\section{METHOD}

This is a descriptive research study aiming at determining the empathetic tendency levels of athletes dealing with team and individual sports. Additionally, in this study, the differences were examined concerning gender and sports experience variables. In total, 524 volunteer athletes ( 232 males and 292 females) participated in the study, whose ages ranged between 15 and 27. Branch distributions of the participants are given below. The "Empathy in the Sports Environment (ESE)" scale, which was developed by Erkuş and Yakupoğlu (2001), was used in the study for the data collection. The ESE, which was comprised of 16 items, is a four pointlikert scale and it is evaluated under two dimensions as emotional empathy and prediction (cognitive) dimensions. The Cronbach alpha values concerning the sub-dimensions were determined as, respectively, .72 and .79 . The least possible score to be gained from the emotional empathy subdimension was 5 and the highest score was 20, while the least value was 11 and the highest was 44 for the prediction dimension.

The SPSS 22.0 was used in the analyses of the research data. The Independent Samples $\mathrm{T}$ test was employed for the paired comparisons, and the Spearman's rho correlation analysis for determining the relations among the variables. The significance level was accepted as $p<0.05$ in the evaluation of the results.

Table 1. Branch Distribution of Participating Athletes

\begin{tabular}{lcc}
\hline Branch & $\mathrm{n}$ & $\%$ \\
\hline Football & 123 & 23.5 \\
\hline Volleyball & 224 & 42.7 \\
\hline Basketball & 57 & 10.9 \\
\hline Tennis & 37 & 7.1 \\
\hline Athletics & 26 & 5.0 \\
\hline Ping pong & 15 & 2.9 \\
\hline Badminton & 10 & 1.9 \\
\hline Handball & 32 & 6.1 \\
\hline Total & 524 & 100.0 \\
\hline
\end{tabular}

\section{FINDINGS}

The comparison of the empathy levels of team and individual athletes are given in the Table 2. It was determined that there was statistically no significant difference concerning the emotional empathy sub-dimension $(p>0.05)$. It was also determined that there was statistically significant difference in favor of the athletes dealing with team sports for the prediction dimension $(p<0.05)$.

In general, when the average scores were examined, it was determined that the average scores of the emotional empathy and prediction dimension were high.

The comparison of the empathy levels of the research group concerning the gender variable is given in Table 3. It was determined that there was a statistically significant difference in favor of the females in the emotional empathy sub-dimension, while there was statistically significant difference in favor of the males concerning the prediction dimension $(\mathrm{p}<0.05)$.

The relationship between the sports experience and the empathy levels of the research group is given in Table 4. Accordingly, it was determined that there was a positive and weak relationship between the sports experience and prediction dimension. In other words, the higher the sports 
experience of the individuals, the higher their

empathy tendency levels.

Table 2. Comparison of the empathy levels of athletes dealing with team and individual sports

\begin{tabular}{llccccc}
\hline & Branch & $\mathbf{N}$ & Mean & Sd. & t & p \\
\hline \multirow{2}{*}{ Emotional Empathy } & Team sports & 412 & 17,33 & 2,59 & \multirow{2}{*}{1.451} & \multirow{2}{*}{.147} \\
\cline { 2 - 5 } & Individual sports & 112 & 16,92 & 2,87 & & \\
\hline \multirow{2}{*}{ Prediction Dimension } & Team sports & 412 & 31,06 & 4,94 & \multirow{2}{*}{2.405} & \multirow{2}{*}{017} \\
\cline { 2 - 5 } & Individual sports & 112 & 29,78 & 5,22 & & \\
\hline
\end{tabular}

Table 3. The comparison of the empathy levels of the research group concerning the gender variable

\begin{tabular}{|c|c|c|c|c|c|c|}
\hline & Gender & $\mathbf{N}$ & Mean & sd & $\mathbf{t}$ & p \\
\hline Emotional & Male & 232 & 16.93 & 2.50 & \multirow{2}{*}{-2.499} & \multirow{2}{*}{.013} \\
\hline Empathy & Female & 292 & 17.51 & 2.76 & & \\
\hline Prediction & Male & 232 & 31.60 & 4.48 & \multirow{2}{*}{3.318} & \multirow{2}{*}{.001} \\
\hline Dimension & Female & 292 & 30.15 & 5.34 & & \\
\hline
\end{tabular}

Table 4. The relationship between the sports experience and the empathy levels of the research group.

Emotional Empathy

\begin{tabular}{cccc}
\hline \multirow{2}{*}{ Sports Experience } & $\mathbf{r}$ & $.092^{*}$ & $.265^{* *}$ \\
\cline { 2 - 4 } & $\mathbf{p}$ & .035 & .000 \\
\hline
\end{tabular}

\section{DISCUSSION \& CONCLUSION}

In this study, which was conducted to examine the empathy levels of the athletes dealing with team and individual sports, the relationships were also examined concerning the gender variables and sports experiences of the athletes, and the obtained results are discussed in this part.

While there was statistically no significant difference concerning the branch status in the emotional empathy sub-dimension, it was determined that the athletes dealing with the team sports had higher scores in the prediction (cognitive empathy) dimension. Additionally, when the average scores were examined, it was determined that the average scores of the emotional empathy and prediction dimensions were high. Therefore, it can be stated that the empathy tendencies of the participant athletes are high. When previous studies conducted on athlete groups are examined, it is generally stated that the empathy behaviors of athletes are high $(9,25,24,17,16,27,2,21)$.

It was determined that there was a statistically significant difference in favor of the females in the emotional empathy sub-dimension, while there was statistically significant difference in favor of the males in the prediction dimension. When the studies are examined in the literature, it is stated that the females have higher emotional and general empathy tendency levels $(4,17,19,13,20,22,9,25,16,27,24$, and 2). In a recent study, it was stated that the level of empathic tendency of senior field hockey athletes was also higher in female athletes (18). However, there are findings indicating that empathic tendency does not differ in terms of gender variable (3). This result might have emerged from the fact that females give more emotional reactions to events compared to males.

It was concluded that, the higher the sports experience of the research group, the higher the emotional and cognitive empathy tendency levels. When the studies in the literature are examined, it is observed that there are findings indicating that the cognitive empathy increases with the sports experience $(7,16$, and 27$)$.

As the conclusion, it was determined that there was statistically no significant difference between the athletes dealing with team and individual sports concerning the emotional empathy dimension; however, it was determined that the athletes dealing 
with team sports gained higher scores in the prediction dimension; it was found that the emotional empathy scores of the female athletes were higher for the gender variable and the male athletes had higher scores concerning the prediction dimension. Considering the sports experience dimension, it was determined that the higher the years of experience, the higher the levels of emotional empathy and prediction.

\section{REFERENCES}

1. Akvardar Y., Ünal B., Günay T., Kırak S., Bozabalı Ö., Demiral Y. Empati Öğrenilebilir mi? Tıp Fakültesi Dönem 1 Öğrencilerinde İletişim Becerileri Kursunun Empatik Yanıt Verme Becerisi Üzerine Etkisi. Dokuz Eylül Üniversitesi Tıp fakültesi Dergisi, Eylül: 2002;162-172.

2. Arslanoğlu C. Farklı Bölümlerde Öğrenim Gören Beden Eğitimi ve Spor Yüksek okulu Öğrencilerinin Empatik Eğilim Düzeyleri ve Saldırganlık İliş̧isinin İncelenmesi. Doktora tezi, Gazi Üniversitesi / Eğitim Bilimleri Enstitüsü, Ankara, 2012.

3. Ayaş EB., İnan H., Kartal M., Gacar A. Spor Eğitimi Alan Üniversite Öğrencilerinin Empati Düzeylerinin Farklı Değişkenler Açısından Karşılaştırılması, International Journal of Social Science. 2016; 53(2):459-466.

4. Aydın A. Empatik Becerinin Çeşitli Değişkenler Açısından İncelenmesi, Yayınlanmamış Yüksek Lisans Tezi, Ege Üniversitesi Sosyal Bilimler Enstitüsü.

5. Borke H. (1973). The Developmentof Empathy In Chinese And American Children Between Three And Six Years O Age :A Cross-Cultralstudy.Devolopmental Psycholog,1996.

6. Budak S. Psikoloji Sözlüğü. Bilim ve Sanat Yayınları, Ankara, 2000.

7. Çimer Ö. Çeşitli Meslek Gruplarında Çalışan Kişilerin Empatik Eğilimleri, Selçuk Üniversitesi Sosyal Bilimler Enstitüsü, Yüksek Lisans Tezi, Konya, 1998;34.

8. Davis, M.H. Measuring individual differences in empathy: Evidence for a multidimensional approach. Journal of Personallty and Social Psychology, 1983;44(1):113-126.

9. Dorak F., Vurgun N. Takım Sporları Açısından Empati ve Takım Birlikteliği İlişkisi. Spormetre Beden Eğitimi ve Spor Bilimleri Dergisi, 2006;4(2):73-77.

10. Dökmen Ü. İletişim Çatışmaları ve Empati. 22.Baskı, Sistem Yayıncılık, s.149-150, İstanbul, 2003.

11. Dökmen Ü. Sanatta ve Günlük Yaşamda İletişim Çatışmaları ve Empati", 9.Baskı, Sistem Yayıncılık, İstanbul,1998

12. Dökmen Ü. Yeni Bir Empati Modeli ve Empatik Becerinin İki Farklı Yaklaşımla Ölçülmesi. Psikoloji Dergisi, 1990;7(24):4250.

13. Duru E. Öğretmen Adaylarının Empati-Yardım Etme Eğilimleri İlişkisi ve Yardım Etme Eğiliminin Bazı Değişkenler Açısından İncelenmesi. Pamukkale Üniversitesi Eğitim Fakültesi Dergisi, 2002;12: 21-36.
14. Eisenberg N., Miller PA. The relatian of empaty to prosocial and related behaviors. Psychologlcal Bulletin, 1987;101, 91119.

15. Eisenberg N., Strayer J. Empathyandlts Development. Cambridge: Cambridge University Press, 1987.

16. Erkmen, G. Selçuk Üniversitesi Beden Eğitimi ve Spor Yüksek okulunda Öğrenim Gören Öğrencilerin Empatik Eğilimlerinin Sporda Tercih Ettikleri Liderlik Davranışları ile Karşılaştırılması, Yayımlanmamış Yüksek Lisans Tezi, Selçuk Üniversitesi, Konya, 2007.

17. Erkuş A., Yakupoğlu S. Spor Ortamında Empati Ölçeği (SEM) Geliştirme Çalışması. Hacettepe Spor Bilimleri Dergisi, 2001;12(1):22-31.

18. Karabulut, E.O., Pulur, A. Üst Düzey Çim Hokeyi Sporcularının Empatik Eğilim Düzeylerinin Farklı Değişkenler Bakımından İncelenmesi. Niğde Üniversitesi Beden Eğitimi Ve Spor Bilimleri Dergisi, 2016;Cilt 10, Sayı 1, 2016

19. Karakaya A. D. Akdeniz Üniversitesindeki Hemşirelik Öğrencilerinin Empati Becerileri. İstanbul Üniversitesi. Sağlık Bilimleri Enstitüsü. Yüksek Lisans Tezi. İstanbul, 2001.

20. Korkmaz, H., Şahin, E., Kahraman, M., Öztürk, F., Uludağ Üniversitesi Eğitim Fakültesi Beden Eğitimi Ve Spor Bölümü Öğrencilerinin Empatik Becerilerinin Yaşa Göre Karşılaştırılması. Uludağ Üniversitesi Eğitim Fakültesi Dergisi, 2003;17(1):95-103.

21. Korur EN., Öncü E., Kılıç SK. The Relationship between Critical Thinking and Empathic Tendency: The Example of Preservice Physical Education Teachers. Journal of Computer and Education Research. 2016;4(8):179-204.

22. Öztürk F. Ş., Koparan N. H., Efe M., veÖzkaya G. Antrenör ve Hakemlerin Empati Durumlarının Araştırılması. Spormetre Beden Eğitimi ve Spor Bilimleri Dergisi. 2004;1(1):19-25.

23. Smith, K. D., Keating, J.P., Stotland, E. Altruism reeonsidered: The effeet of denying feedback on a victim's status to empathetie witnesses. Journal of Personalltiand Social Psychology, 1989; 57,641-650.

24. Solak, N. Spor Yapan Ve Yapmayan Ortaöğretim Öğrencilerinin Saldırganlık Düzeyleri İle Empatik Eğilim Düzeyleri Arasındaki İlişkinin İncelenmesi (Çorum ili örneği). Yayımlanmamış Yüksek Lisans Tezi, Gazi Üniversitesi Eğitim Bilimleri Enstitüsü, Ankara, 2011.

25. Uygun E. Psikiyatri Servisinde Çalışan Hemşirelerin Empati Beceri Düzeylerinin Belirlenmesi. Yüksek Lisans Tezi. İstanbul, 2006

26. Winefield HR., Chur-Hansen A. Evaluating The Outcome Of Communication Skill Teaching For Entry-Level Medical Students: Does Knowledge Of Empathy İncrease. Medical Education, 2000;34:90-94

27. Yılmaz İ., Akyel Y. Beden Eğitimi Öğretmen Adaylarının Empatik Eğilim Düzeylerinin Çeşitli Değişkenler Açısından Incelenmesi. Ahi Evran Üniversitesi Eğitim Fakültesi Dergisi, 2008; 9(3): 27-33. 